\title{
A transcrição e o terceiro de bôa fé
}

\section{Octavio Moreira Guimarães}

1. A aquisição de direitos reais póde realizar-se de três maneiras: -.- ou mediante um ato solene perante a justiça, com o fito de se operar a tradição e a inscrição; ou pelo simples consenso dos contratantes, ou, então, pelo registro do contrato.

Meulenaere, anotando o art. 873 do Cód. Civil alemão, assim se expressa: - "Na maior parte da Alemanha o direito imobiliário tem por base a organização do grundbuch ou registro de imoveis, cujo fim é assegurar a propriedade e o crédito real imovel.

As duas condições essenciais são o acôrdo, ou a entrega e a inscrição.

Realizado esses atos, transfere-se a propriedade ao adquirente. Mas essa transferência independe das relações jurídicas das partes. A propriedade permanece adquirida pelo próprio adquirente, embora se anule o contrato de compra e venda, de onde proveio o acôrdo".

Há, assim, no direito alemão, como no direito romano, dois atos autônomos: - o que se refere ao contrato, e que regula os interesses dos contratantes e suas obrigações recíprocas, e o que respeita à transferência da propriedade, ou à constituição de direitos reais, alheio ao primeiro, e que se efetua ante o Poder Público.

A aquisição de direitos reais, no direito francês e no italiano, se verifica pelo mero consenso dos contratantes.

$O$ contrato se perfaz, ou torna-se definitivo, assim que os interessados manifestam seu acôrdo. Realizam-se, então, todos os requisitos que formam o ato. 
A transcrição é, assim, tão somente um fato, desligado do ato jurídico e só necessário para que os terceiros conheçam o que se contratou.

Os contratos são consensuais; completam-se pelo consentimento dos interessados. Todavia é claro que tais atos sem repercussão ou que não têm sinal que os releve suficientemente, haveriam de ser danosos ao terceiro.

Para obviar os inconvenientes dessa situação, idearam-se duas regras jurídicas: - a primeira é a de que a posse de cousa movel equivale a título; e a outra, a segunda, é que os contratos referentes a imóveis, embora perfeitos, pela vontade dos interessados, sómente hão de valer quanto ao terceiro, quando registrados.

O registro é, desse geito, um meio de publicidade, para que os atos jurídicos já válidos, se tornem por sua vez eficazes em relação aos terceiros.

No direito brasileiro, entretanto, seguiu-se outra orientação - a do direito romano, isto é, o contrato de natureza real sómente se consuma, pela tradição, ou pela transcrição (re perficitur).

A tradição e a transcrição são, pois, partes componentes do ato, elementos substanciais do contrato.

2. Transcrito o contrato, indaga-se qual há de ser a situação do terceiro de bôa fé, quando o ato se anula ou se desfaz.

Em regra o registro imobiliário se ordena conforme os princípios da publicidade, da inscrição e da legalidade.

o princípio da publicidade pressupõe que o ato esteja perfeito, ou contenha todos os requisitos precisos à sua existência.

A publicação, como explica o próprio termo, tem o intento de noticiar a ocorrencia, para que terceiros não sofram as consequencias de atos danosos.

$\mathrm{O}$ ato tem toda eficácia, e obriga os contratantes. Todavia sómente afetará o terceiro, quando se manifestar por uma fórma pública. 
O princípio da inscrição significa que o ato nem se formará, nem se modificará, nem se extinguirá, enquanto não registrado. Não bastará o consentimento das partes; é preciso ainda, como elemento constitutivo do ato, o seu registro.

o princípio da legalidade quer dizer que o ato jurídico, a despeito de transcrito, se atém e ainda se subordina aos antecedentes de onde deflue, para se verificar, por exemplo, a livre disponibilidade do tradens, o seu consentimento, ou a observancia das regras legais.

o Código Civil Brasileiro adotou, sem nenhuma dúvida, porque por disposição expressa, o princípio da inscrição: - "os atos sujeitos à transcrição (artigos 531 e 532 ns. II e III) não transferem o dominio senão da data em que se transcreverem (856, 860 parágrafo único") — art. 533.

A divergencia desponta quanto ao princípio da legalidade, entendendo-se, de uma parte, que o ato oneroso transcrito não é reexaminado, e que o terceiro de bôa fé adquire, qualquer que seja a situação jurídica anterior; e opinandose, de outro lado, diferentemente, ou que o Código Civil Brasileiro não acolheu a tese do Código Civil Alemão, mas guardou a tradição do direito pátrio e propendeu pelo princípio da legitimidade, isto é, pela casualidade do ato, ou pela sua sujeição a exame e investigação.

3. O Código Civil Alemão difere, entretanto, do Código Civil Brasileiro não só quanto ao ato do registro como tambem referentemente à tutela do terceiro.

No Código Civil Brasileiro não se inseriu a validade do ato oneroso em relação ao terceiro de bôa fé. Presumem os intérpretes que esse deva ser o sentido da lei, mas não existe preceito legal idêntico ao art. 892 do Código Civil Alemão: - "Si quelqu'un a acquis par acte juridique un droit sur un fonds ou un droit. sur pareil droit, le contenu du registre foncier est censé exact à son profit, $\dot{a}$ moins qu'une contestation de l'exactitude n"ait été inscrite ou que l'inexactitude ne soit connue de l'acquéreur" 
Daí a conclusão do eximio civilista José Augusto Cesar: "o legislador brasileiro sancionou o primeiro princípio (a presunção do art. 859), mas omitiu o segundo (fé pública do registro). Logo, cumpre interpretar sem restrição o art. 860 , isto é, o prejudicado terá ação de retificação do registro, ainda que o imovel tenha sido alienado a terceiros de bôa fé por quem figurava indevidamente como dono na transcrição" (Revista da Faculdade de Direito de São Paulo, v. 31/425-427).

Além de não dispôr, como dispôs o Código Civil Alemão, o Código Civil Brasileiro regulou o registro por uma técnica diversa.

No direito alemão o registro independe do ato jurídico, ou das relações jurídicas dos interessados, como expressa o art. 873, e adverte Meulenaere, seu tradutor e anotador: - "o adquirente adquire definitivamente, embora a venda se desfaça ou se anule. Ao vendedor não resta nessa hipótese senão uma ação pessoal de e nriquecimento injustificado".

E no direito brasileiro o negócio jurídico é que se transcreve. O registro é um dos requisitos do ato; uma das suas propriedades constitutivas. O contrato se compõe de vários fatos, entre os quais se inclue o registro.

Há de ser, pois, incompreensivel que, anulado o ato, ainda permaneça viva, com efeitos jurídicos, a transcrição que é uma das suas parcelas integrantes?

$\mathrm{Si}$ os demais termos se extinguiram, como ha de sobreviver um deles, restringindo a ação de nulidade, ou limitando seus efeitos?

4. Os que divergem desse entendimento dizem que o Código Civil Brasileiro adotou o princípio da fé pública no art. 859, que se expressa desta maneira:

- "Presume-se pertencer o direito real d̀ pessoa em cujo nome se inscreveu ou transcreveu".

Parce, entretanto, que não têm razão esses que assim opinam: 
a) Porque a disposição legal se refere sómente ao titular do direito, para se presumir que seja sua a propriedade do direito registrado. Não designa o terceiro, para afirmar, como o Código Civil Alemão, que valerá tambem a aquisição onerosa, de bôa fé. $E$ é óbvio que a lei ha decompreender unicamente a hipótese que especifica;

b) Porque o Código Civil Alemão dispôs no art. 891, identicamente ao que dispõe o art. 859 citado do Código Civil Brasileiro: "Lorsqu'un droit a été inscrit en faveur de quelqu'un au registre foncier, l'on présume que ce droit lui apartient".

Se tal preceito bastasse para validar o negócio do terceiro, não precisaria que esse Código designasse, como designou, no art. seguinte 892 - que "le contenu du registre foncier est censé exact à son profit".

Se num artigo o Código Alemão exprime a presunção de propriedade, e no imediato destaca a aquisição do terceiro, é porque a primeira disposiçấo do mesmo teor que o artigo 859 do C. C. Brasileiro não autoriza a estensão que lhe está sendo atribuida;

c) Porque a presunção estatuida no art. 859 do Código Civil Brasileiro é condicional, isto é, sujeita à contrariedade das provas. $\mathrm{E}$ assim sucede por dois motivos, primeiro, porque nos termos do art. 251 do Código de Processo, "a prova contra presunção legal será sempre admitida, salvo quando a própria lei a excluir"; e, segundo, porque, conforme o art. 860 do Código Civil, "si o teor do registro de imoveis não exprimir a verdade, poderá o prejudicado reclamar que se retifique". E' lícita a retificação a qualquer tempo, pois a lei não consigna restrição alguma. Portanto, pela própria lei, o terceiro de bôa fé perderá a aquisição, desde que o prejudicado promova a retificação do registro que não traduzir a verdade;

d) Porque tenta-se em suma aplicar o preceito legal à hipótese que ele não mirou. Si a lei tem como desígnio reger um determinado estado de coisas, evidentemente não é justificavel a pretenção de concentrar-se aí uma outra si- 
tuação dissemelhante. $\mathrm{O}$ artigo referido do Código Civil não compreende a espécie. Aí não se trata de uma presunção estabelecida para favorecer o terceiro de bôa fé. Mas o intento da lei é determinar a preferencia entre vários concorrentes do mesmo direito, ou de interessados que adquiriram a mesma coisa do mesmo proprietário. Esse conflito de interesses pode surgir. E' possivel, por exemplo, que o dono da coisa a aliene a mais de uma pessoa. Estadeiase, então, um caso que a lei precisa regular; e efetivamente regula, dispondo que, realizada a transcrição ou a inscrição, já não póde o prejudicado arguir o seu direito, porquanto ha de prevalecer, nesse caso, o ato registrado.

Acrescentam ainda os opositores que o art. 834 do Código Civil permite que se levantem dúvidas sobre a legalidade da transcrição, e isso assinala que o ato é examinado, e portanto deve subsistir, afinal, como definitivo.

Essa afirmação nem é exata, porque o ato transcrito pode ser anulado, e nem tem a lei a extensão que lhe é atribuida, porque a investigação se limita a exterioridade do ato.

Diz-se, por fim, que o art. 968 do Código Civil é terminante, pois preceitua que "aquele que indevidamente recebeu um imovel, o tiver alienado em bôa fé, por título oneroso, responde sómente pelo preço recebido".

$O$ argumento se ressente de uma confusão, ou de uma transposição injustificavel de princípios.

Aí se diz que o accipiens de bôa fé restitue somente o preço.

Dispôs-se dessa maneira para proteger a bôa fé do accipiens.

Não se cogita da bôa fé do teceiro. Quer dizer que o terceiro adquire validamente, não pela transcrição, mas em virtude do estado subjetivo de quem lhe vendeu.

$E^{\prime}$ evidente que, referindo-se a lei à situação do accipiens, só ha de abranger a espécie que designa, sem possibilidade de se estender à hipótese diferente, isto é, ao terceiro de bôa fé. 
E' lícito, pois, concluir, como concluiu o professor SoRiAno Neto - "Publicidade Material do Registro Imobiliario", que o Código Civil Brasileiro não adotou no art. 859, o princípio da fé pública, mas consignou aí unicamente o principio da prova, para poupar ao reivindicante as dificuldades de investigar e demonstrar o dominio do seu antecessor, como impunha o direito anterior (LAFAyetTe, "Direito das Coisas", pag. 82).

Essa conclusão pode robustecer-se com os argumentos a contrário sensu que o Dr. A. Gonçalves de Oliveira aduz, fundado nos institutos da prescrição ordinária e da evicção (Arquivo Judiciário, v. 52, Suplemento, p. 27/29).

- Se o Código Civil Brasileiro houvesse aceito o princípio da fé pública, não precisaria especificar, como especificou no art. 551, o usucapião ordinário como modo de aquisição, pois esta haveria então de decorrer do título e da bôa fé, sem carecer da posse que a lei ajuntou.

$\mathrm{E}$ no art. 1.117 admitiu a evicção, ou a possibilidade de perda do adquirente de bôa fé, quando dispôs que "não póde o adquirente demandar pela evicção, si sabia que a coisa era alheia ou litigiosa", querendo significar que o direito às vantagens da evicção sómente poderia advir dos atos de bôa fé.

5. Si o registro não exprimir a realidade, o terceiro de bôa fé não adquirirá. Promova-se a retificação, como permite o art. 860 do Código Civil; prove-se que o proprietário inscrito não tem de fato o dominio, e o direito do terceiro sossobrará.

Si o ato não for licito, ou se anular, ainda nesse caso o direito do terceiro se extinguirá.

Prevalecerão, então, as regras juridicas: nemo plus juris in alium transferre potest quam ipse habet. Resoluto iure dantis, resolvitur et ius concessum.

Esses princípios, de indole geral e corrente, sómente não predominam, havendo um preceito expresso de lei, tolhendo a sua aplicação. 
Si é certo que o efeito não pode sobreexceder à causa, há de ser irrecusavel tambem que, resolvido o ato originário, todos os demais atos subsequentes se resolverão.

Para que não domine essa conclusão, ou não se aplique a regra, seria preciso que um dispositivo legal se interpusesse, preceituando diferentemente.

No direito civil brasileiro não existe nenhuma disposição categórica sobre o assunto, isto é, que declare que o ato transcrito produz efeitos jurídicos em relação ao terceiro de bôa fé, apesar da sua resolução posterior.

$\mathrm{E}^{\prime}$ certo que, ás vezes, os princípios jurídicos preenchem a falta da norma legal, ou corrigem a sua deficiencia. Há, por exemplo, o princípio da bôa fé, que, em casos excepcionais, valida o ato efetuado, embora o transmitente não possua o direito transferido.

Mas esse acontecimento sómente ocorre pela culpa do verdadeiro titular do direito; e, então, nessa hipótese, o princípio da responsabilidade supre a inexistencia da vontade, e o ato que normalmente havia de ser negativo, torna-se positivo, em virtude da falta do interessado.

Sucede essa anormalidade, por exemplo, quanto ao herdeiro aparente, cujo negócio deveria caír por não lhe pertencer a propriedade, e que, no entanto, prevalece. Torna-se válido esse ato pelo procedimento do herdeiro legítimo, permitindo, por sua inércia ou negligencia, que se ostente a situação enganosa.

Para que fosse possivel a aplicação do princípio da bôa fé aos atos transcritos, era mistér assim que se positivasse a responsabilidade do transmitente quanto ao ato da transcrição, ou que o seu defeito ou a sua inexatidão proviessem da sua culpa.

Portanto, não existindo preceito legal sobre a eficácia absoluta da transcrição, e não sendo admissivel a aplicação da regra da bôa fé, é licito concluir que, no direito civil brasileiro, resolvido o ato originário, se resolverão tambem todos os demais atos sucessivos. 